\title{
SOCIALIZATION AND TRAINING OF WEB-BASED CENDANA POSYANDU INFORMATION SYSTEM IN KAHURIPAN VILLAGE, TASIKMALAYA CITY
}

\author{
Hani Rubiania), Eddy Samsoleh, Sulidar Fitri and Shofia Rahmah Soprani \\ Program Studi S1 Teknik Elektro, Universitas Muhammadiyah Tasikmalaya, Tasikmalaya, Indonesia \\ Program Studi 1 Pendidikan Teknologi Informasi, Universitas Muhammadiyah Tasikmalaya, Tasikmalaya, \\ Indonesia \\ a)Corresponding Author: hani.rubiani@umtas.ac.id
}

\begin{abstract}
Information system is an integrated system that provides information or data to support various operational activities, management, and decision-making functions of an organization or company. Information systems are needed in an organization because what determines the running of an organization is the information it has, such as in making reports given to the leadership, depending on whether the information is accurate or not. As is the case in non-profit organizations in the community, namely Posyandu. Posyandu (Pos Pelayanan Terpadu) is a form of Upaya Kesehatan Bersumberdaya Masyarakat (UKBM) carried out by, from and with the community, to empower and provide convenience to the community to obtain health services for mothers, infants and toddlers. The implementation of the Posyandu which is routinely carried out every month is carried out by health cadres whose workforce is voluntary and is chosen by local residents and is tasked with fostering the community. The purpose of this community service program is to provide knowledge and understanding to Posyandu cadres so that they can provide maximum health services to the community, especially health service administration during registration, recording and reporting, namely by providing socialization of the use of the Web-Based Posyandu Information System for Cendana Posyandu cadres in Kahuripan Village, Tasikmalaya City. It is hoped that with this socialization, the cadres can use the Posyandu Information System properly so that the health services provided can run optimally. Features that exist in the Posyandu Information System include recording of mother's data, recording of child data in it along with reporting of weighing and giving vitamins.
\end{abstract}

Key words: Information system, Posyandu, Community service program, Socialization

\section{INTRODUCTION}

Posyandu currently has a significant role to support public health services. The role of Posyandu is accompanied by community participation which is increasingly visible after the emergence of Posyandu as a form of community-based health efforts. Posyandu activities are run by self-selected community members, where the selected members will later be trained to become a health cadre under the assistance of the local Puskesmas (Depkes 2014)(Depkes 2011). This is a manifestation of the community's role in health development. This is also in line with the statement that Posyandu is one of the health facilities managed from, by, for, and with the community (Departemen Kesehatan RI 2007). 
Posyandu is a form of integrated health services carried out in a puskesmas working area (Ika Ratna Indra Astutik, Hana Catur Wahyuni 2017). The place for implementing integrated program services is usually at the hamlet or village hall. Posyandu services are maternal and child health services, family planning, eradication of infectious diseases by immunization, prevention of diarrhea and nutrition. Posyandu targets are pregnant women, breastfeeding mothers, couples of childbearing age and toddlers. Kahuripan Village, Tasikmalaya City has 19 Posyandu, one of which is Cendana Posyandu. So far, the Cendana Posyandu in the Kahuripan sub-district, Tasikmalaya City has always carried out its obligations in providing health services to the community. In posyandu there are basic health services which are health services that aim to accelerate the reduction of maternal and infant mortality, which includes at least 5 activities, namely, KIA, family planning, immunization, nutrition and diarrhea control. Therefore, Posyandu strives to provide health services to the community by always routinely implementing health programs that are recommended by the government.

In addition to health service activities, Posyandu also provides health education, especially health education related to the health of pregnant women and toddlers, such as immunization, development of toddler nutrition, sanitation, etc. So far, administrative services and reporting at the Cendana Posyandu still use the conventional system where all service processes are still recorded using paper and require a long time in making reports so that administrative services to the community become less effective and efficient. Referring to the results of the analysis that has been carried out, the main problem faced by Posyandu cadres in providing health services is how to provide optimal health services to the community, especially in terms of service administration such as registration, recording and reporting.

\section{METHOD}

In carrying out this community service, it is planned to be carried out in four stages, namely: the preparation stage, the implementation stage, the trial and implementation stage and the evaluation stage.

The following are the four stages:

1. Preparation Stage

In this first stage, namely the preparation stage, socialization activities will be carried out on the plan for implementing community service to Cendana Posyandu cadres with the following activity plans:

a. Observing the current system and existing administrative records. This observation stage was carried out on the process of implementing the Cendana Posyandu which carried out its activities with a 5-table system starting from the cadres registering the incoming targets which were recorded in the administration book at table 1, then weighing and measuring height was then recorded in the administration book as well as in the KMS. This recording is also done when toddlers get immunizations and vitamins. Manual recording causes the resulting information to be less accurate and relevant as well as less effective and efficient, thus affecting the service process and affecting the reporting time to the Tasikmalaya City Health Office.

b. Conducting direct interviews with Cendana Posyandu cadres. The interview stage was carried out to find out what were the obstacles faced by the Cendana Posyandu both in service and in the process of managing Posyandu administrative data. Recording which is still done manually makes it difficult for cadres to carry out the data search process, 
especially the identity and development of toddlers every month. Often the data is recorded twice because the cadres cannot find the existing data.

c. Analyzing the needs of information systems, namely the need for software, hardware, and system users (brainware).

2. Stages of Implementation

As for in this implementation stage, the activities that will be carried out at this stage are:

a. Performing information system design, namely Data Flow Diagram (DFD) design, database conceptual model and information system interface display (Arbie 2004) .

b. Implementing information system design into program codes (Jogiyanto 2005).

3. Stages of trial and implementation

The system is completed, the next stage is the implementation of the information system (Implementation). At this stage the information system is tested first to find out the system is as expected or there are still shortcomings. The system that has been tested and there are no problems begins to be implemented at the Posyandu.

4. Evaluation Stage

The last stage is the evaluation stage, at this stage an evaluation of the implementation of community service activities will be carried out which includes:

a. Implementation of information systems for community service partners.

b. Partners as users perform data processing on the information system.

c. Partners will be given a questionnaire as feedback on this community service activity, the results of which will be evaluated for the sustainability of the program in the field.

\section{RESULTS}

Based on the results of interviews conducted with the head of the Cendana posyandu, the problem experienced was how to make the service process at the posyandu well recorded and easy to make posyandu reports. So far, posyandu reports are still in paper media which are written manually, so errors often occur in recording and making reports. Therefore, posyandu requires an application that can support cadre activities in the posyandu service process from registration to report generation. To overcome this problem, the authors propose a solution by creating a model of the Posyandu information system application to be socialized to cadres so that they have an overview of the use of the Posyandu information system application so that during training they are easier to use the Posyandu information system application. two activities, namely:

1. Field Survey: the activity is carried out by conducting interviews with the head of the Cendana posyandu to find out the training needs needed by the Cendana posyandu. In addition, we and our partners also discussed the preparations for the implementation of the web-based Posyandu information system socialization. Preparation related to the infrastructure and facilities needed during socialization.

2. The socialization of the web-based Posyandu information system application model was carried out on December 13, 2020 at the AT-Taqwa Madrasah, Jalan Cikalang Girang, Kahuripan Village, Tawang District, Tasikmalaya City.

Socialization activities are carried out by providing an understanding of what the posyandu information system is, the benefits of the posyandu information system and the use of posyandu information system applications, and questions and answers. The socialization was carried out for 4 hours starting at 08.00 until 12.00 WIB. Posyandu Information System The webbased Posyandu information system is only an application model that is used for information dissemination material for the Posyandu information system at the Cendana posyandu. There 
are several user interfaces made in the Posyandu information system, namely recording maternal data, recording child data, weighing data reports, recording immunization data, recording vitamin data. The appearance of the application on the Posyandu information system can be seen in the figure.

The Posyandu information system socialization activity was carried out at the AT-Taqwa Madrasah, Jalan Cikalang Girang, Kahuripan Village, Tawang District, Tasikmalaya City. This activity was attended by 11 posyandu cadres and several invited guests. The implementation of socialization activities went well and smoothly. Posyandu cadres are very enthusiastic and interested in the posyandu information system that is presented. They hope that the Cendana posyandu can be used as a pilot posyandu for other posyandu in the Kahuripan Village, Tasikmalaya City, where there is no posyandu that uses information systems in service activities to the community. The photo of the activity can be seen in the picture.

\section{DISCUSSION}

Information system is a unity of elements that interact systematically and regularly to create and shape the flow of information that will support decision-making and exercise control over the company (Sutedjo 2002). The technology of the World Wide Web (WWW) or the web for short, seems to have removed the limitations of place and time in communicating between various communities in all corners of the world. With the rapid flow of the internet, web technology is getting more sophisticated day by day. First introduced and developed by Tim Berners-Lee in 1989, Web version 1.0 is the first step in the internet world (Diablue 2009).

Posyandu is a form of Upaya Kesehatan Bersumberdaya Masyarakat (UKBM) which is managed and organized from, by, for and with the community in implementing health development in order to empower the community and provide convenience to the community in obtaining basic health services to accelerate the reduction of maternal and infant mortality rates. The main activities at the posyandu include monitoring the growth and development of children under five, maternal and child health services such as immunization to prevent disease, diarrhea control, family planning services, counseling and counseling/referral if needed. Activities at the Posyandu consist of 5 activities which include: Maternal and Child Health, Family Planning, Immunization, Nutrition Improvement and Diarrhea Control (Kesehatan 2012).

The Posyandu information system is a series of activities to produce data and information about services for child growth and development processes and basic maternal and child health services which include program coverage, program achievements, continuity of weighing, weighing results and community participation in accordance with needs in an effective and appropriate manner. time for Posyandu managers. Therefore, the Posyandu Information System is an important part of the overall Posyandu development. The material in this socialization and training activity is to socialize and provide information system training that has been made by the community service team previously. This posyandu information system application is made using the Java programming language and MySQL database. This information system will be used to help Cendana posyandu cadres process data on children and toddlers as well as reports from entering, changing, updating, deleting data. So that it can facilitate and make the work of cadres more efficient. 


\section{CONCLUSIONS AND RECOMMENDATIONS}

Community service at the Cendana posyandu has been carried out well and without significant obstacles. With good service team collaboration and the active participation of the posyandu chairman in this service activity, everything has gone as expected and it is hoped that it can provide benefits for community service partners in terms of understanding the description of the use of web-based posyandu information systems. So that if at any time the posyandu information system is applied, the cadres will already know and understand what the posyandu information system is like.

\section{ACKNOWLEDGMENTS}

We express our gratitude to Allah Subhanahu Wa Ta'ala, because for the facilities provided so that this Community Service can run smoothly. This community service can be carried out well with the support of (1) Head of Universitas Muhammadiyah Tasikmalaya (2) Head of LPPM Universitas Muhammadiyah Tasikmalaya (3) Head of Electrical Engineering S1 Study Program (4) Head of Cikalang Girang Village and all community leaders, (5) Head of Tawang District Health Center and all staff, (6) Village Midwives and Cadres of the Cendana Posyandu, (7) S1 Information Technology Education Student of Universitas Muhammadiyah Tasikmalaya. May Allah Subhanahu Wa Ta'ala reward you with the good you deserve. Amen.

\section{REFERENCES}

Arbie. 2004. Manajemen Database Dengan Mysql. Yogyakarta: Andi Yogyakarta.

Departemen Kesehatan RI. 2007. Kesehatan Masyarakat. Jakarta: Sinar Harapan.

Departemen Kesehatan RI. 2014. Sistem Informasi Posyandu. Jakarta.

Diablue, El. 2009. "Perkembangan Teknologi Web." Retrieved (http://eldiablue.wordpress.com).

Ika Ratna Indra Astutik, Hana Catur Wahyuni, Sri Mukhodim Hanum. 2017. "Peningkatan Kualitas

Pelayanan Posyandu Balita Berbasis Sistem Informasi." in SEMNAS PPM 2017.

Jogiyanto. 2005. Analisis Dan Desain Sistem Informasi. Yogyakarta: Andi.

Kesehatan, Kementrian Kesehatan RI Pusat Promosi. 2012. Buku Saku Posyandu. Jakarta: Kementrian Kesehatan RI.

RI, Kementrian Kesehatan. 2011. Buku Panduan Kader Posyandu Menuju Keluarga Sadar Gizi. Jakarta: Kementrian Kesehatan RI.

Sutedjo, Budi. 2002. Perencanaan Dan Pembangunan Sitem Informasi. Yogyakarta: Andi Offset. 


\section{ATTACHMENT}
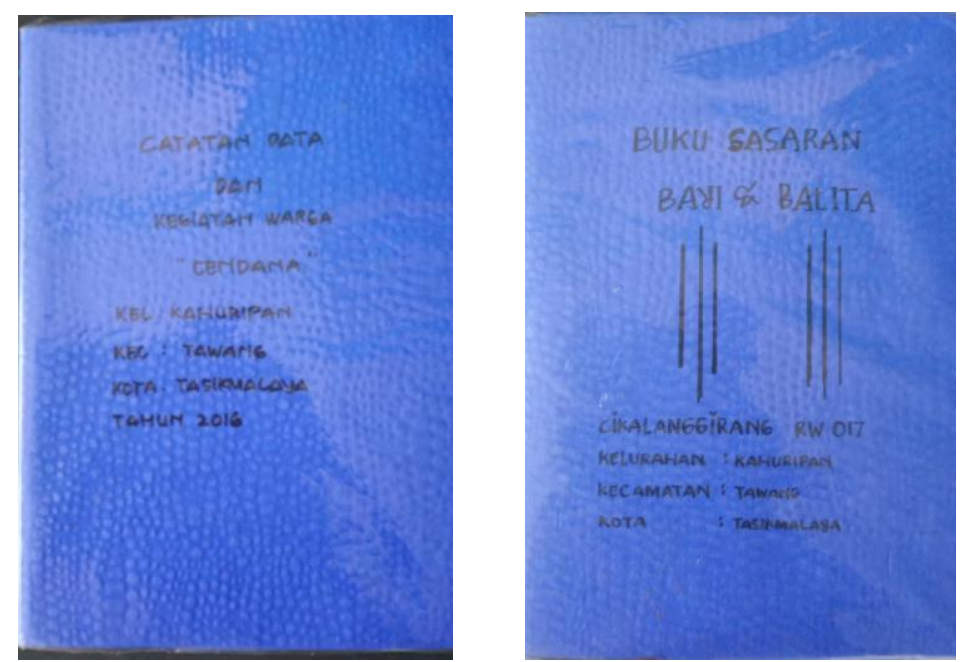

Figure 1. Cendana posyandu administration book

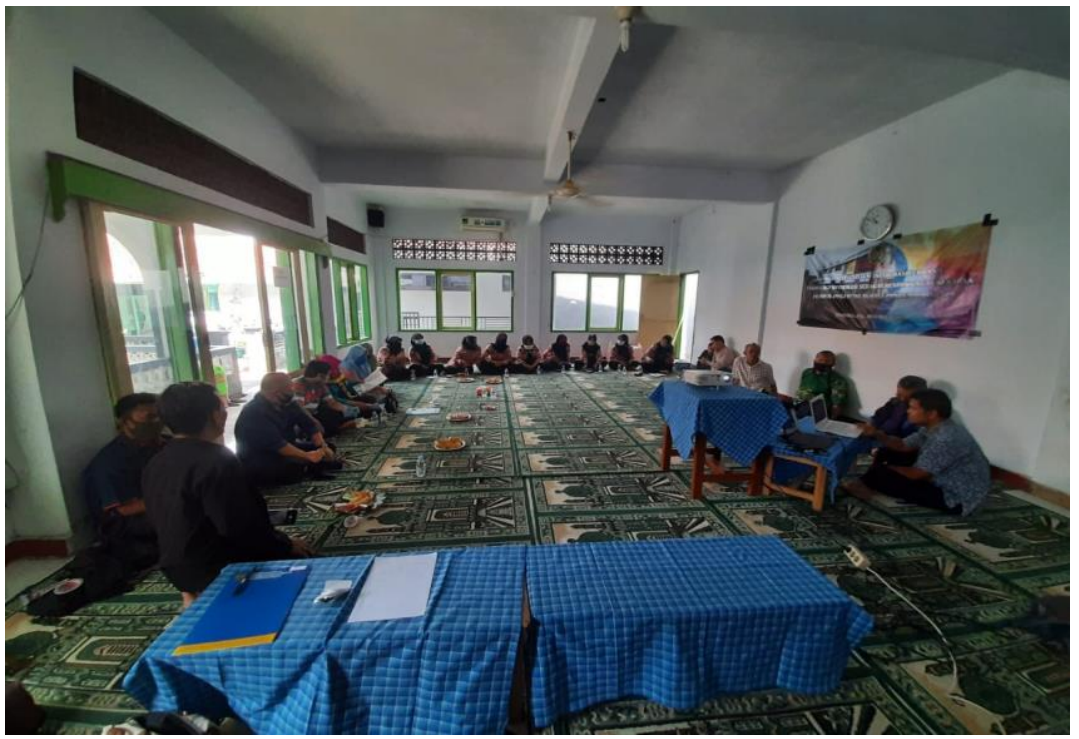

Figure 2. Photo of posyandu information system socialization and training activities 


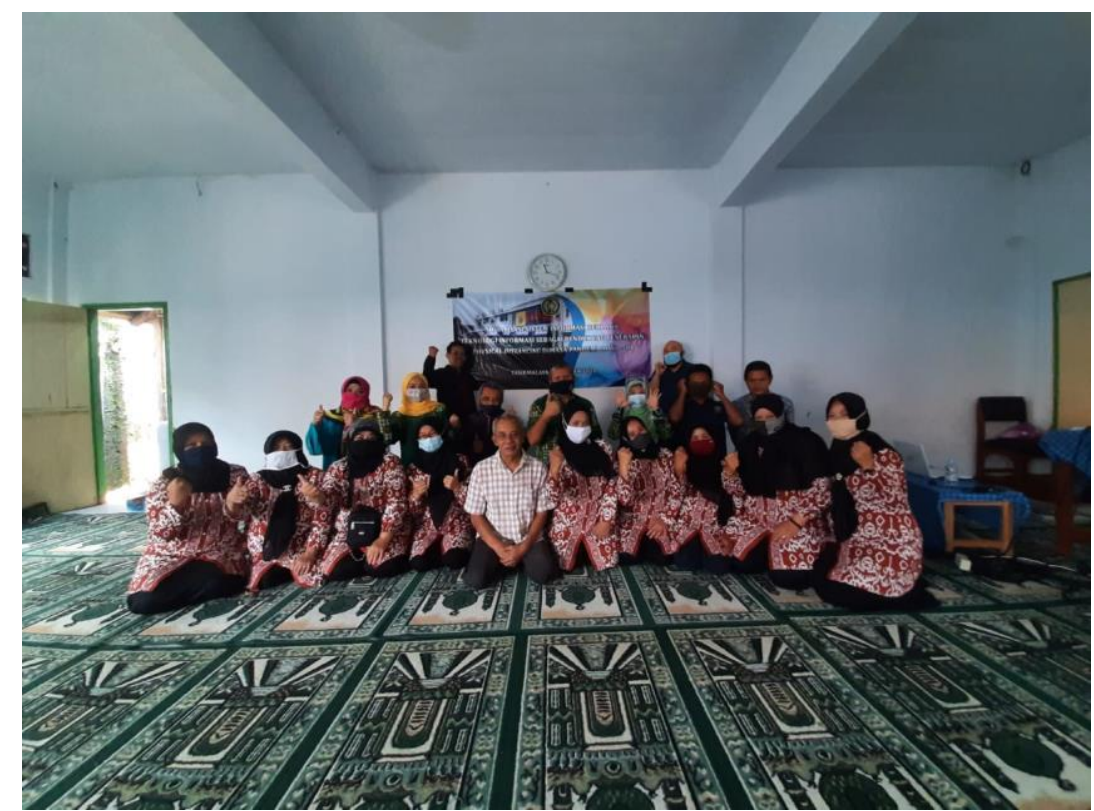

Figure 3. Cadres of the Cendana Posyandu

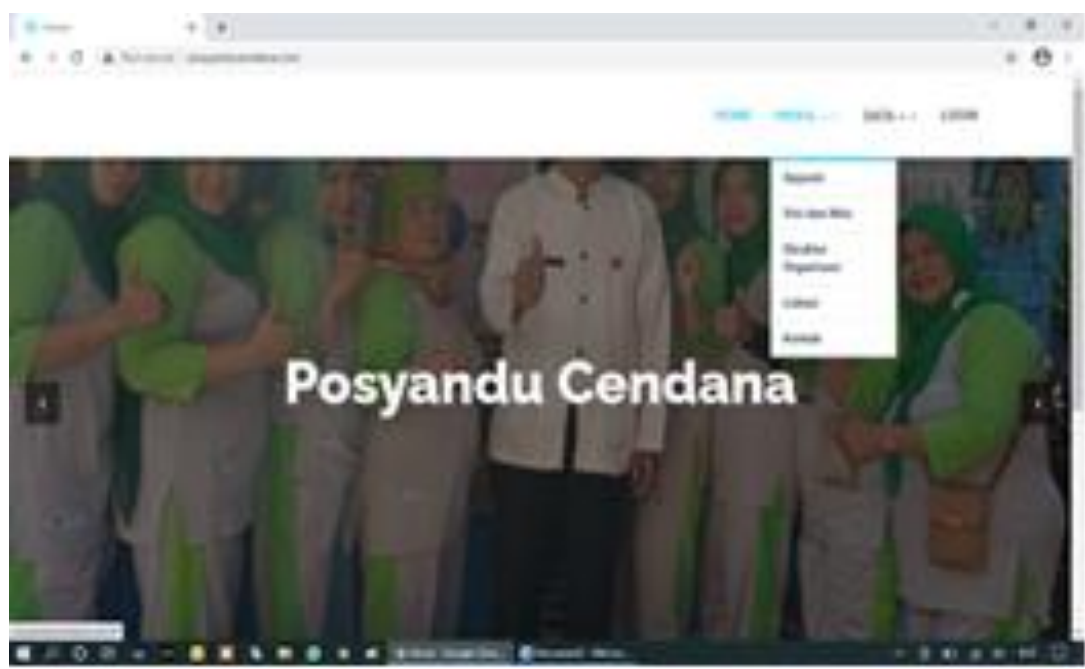

Figure 4. Cendana posyandu information system main page

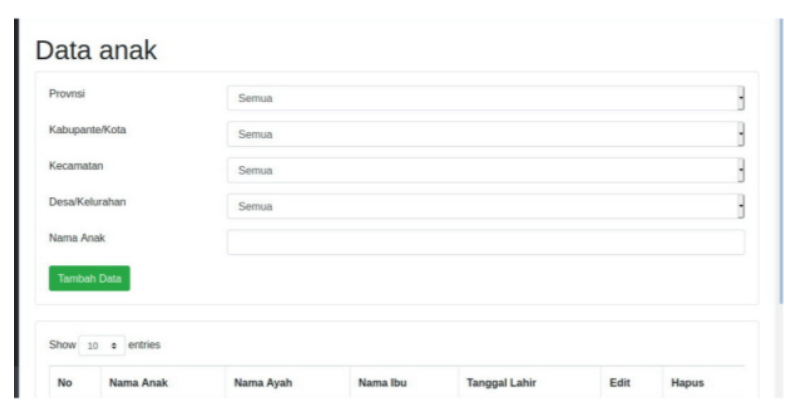

Figure 5. Data Menu 